\title{
Persepsi Siswa Terhadap Pelaksanaan Layanan Bimbingan dan Konseling di Sekolah Oleh Guru Bk di SMA Negeri 5 Mataram
}

\author{
Lalu Abdurrachman Wahid ${ }^{1}$, Noffiyanti ${ }^{2}$, Etty Setiawati ${ }^{3}$ \\ ${ }^{1}$ UIN Mataram \\ ${ }^{2}$ UIN Raden Intan Lampung
}

\begin{tabular}{l}
\hline \hline Article Info \\
\hline Article history: \\
Received Jun $12^{\text {th }}, 2020$ \\
Revised Aug $20^{\text {th }}, 2020$ \\
Accepted Sep $26^{\text {th }}, 2020$ \\
\hline
\end{tabular}

\section{Keyword:}

Persepsi Siswa

Layanan Bimbingan dan

Konseling

Guru BK

\begin{abstract}
Penelitian ini untuk mengetahui Persepsi Siswa Terhadap Pelaksanaan Layanan Bimbingan dan Konseling di Sekolah Oleh Guru BK di SMA Negeri 5 Mataram. Penelitian ini diharapkan dapat mebantu guru BK dalam mengetahui persepsi siswa terhadap pelaksanaan layanan BK yang telah diberikan. Jenis penelitian ini adalah penelitian kuantitatif dengan metode deskriptif. populasi dalam penelitian ini adalah seluruh siswa di SMA Negeri 5 Mataram berjumlah 1104 orang dan Sampel yang diambil dalam penelitian ini adalah 234 siswa. Hasil penelitian secara keseluruhan menunjukkan distribusi frekuensi dan persentase dari enam indikator pelaksanaan layanan BK oleh guru BK di SMA Negeri 5 Mataram ditemukan bahawa pada indikator kedisiplinan dan penampilan guru BK dalam kategori baik sebanyak $61,97 \%$. Indikator wawasan $\mathrm{BK}$ dalam kategori baik sebanyak 58,55\%. Indikator bidang bimbingan dalam kategori baik sebanyak 67,09\%. Indikator jenis layanan BK dalam kategori baik sebanyak $66,24 \%$. Indikator kegiatan pendukung BK dalam kategori baik sebanyak $76,50 \%$. Indikator kinerja dan keterampilan guru BK melaksanakan pelayanan BK di sekolah dalam kategori baik sebanyak 70,94\%. Berdasarkan enam indikator yang diukur di atas, maka dapat disimpulkan bahwa secara keseluruhan persepsi siswa terhadap pelaksanaan layanan BK oleh guru BK di SMAN 5 Mataram menunjukkan dalam katagori baik yakni dengan sumbangan frekuensi 160 atau 68,38\%.
\end{abstract}

\section{Corresponding Author:}

Lalu Abdurrachman Wahid

UIN Mataram

Email: rahman@uinmataram.ac.id

\section{Introduction}

Perkembangan profesi konselor sekolah atau guru bimbingan dan konseling di Indonesia telah diawali sejak tahun 1960-an. Bimbingan dan Konseling masuk kedalam kurikulum sekolah sejak tahun 1965 yang mencantumkan bahwa pelayanan bimbingan dan konseling merupakan layanan yang tidak terpisahkan dari keseluruhan sistem pendidikan di sekolah. Pada Undang-Undang Sistem Pendidikan Nasional (UUSPN) tahun 1989, secara eksplisit menyebutkan pelayanan bimbingan di sekolah dan memberikan kedudukan sebagai tenaga pendidikan kepada petugas bimbingan. Pada saat itu, profesi konselor secara legal formal telah diakui dalam sistem pendidikan nasional. Guru bimbingan konseling merupakan profesi yang sudah diakui keberadaannya di sekolah. Hal ini dapat dilihat pada Peraturan Pemerintah Republik Indonesia Nomor: 74 tahun 2008 tentang Guru pada pasal 15 yang mengatakan, bahwa guru Bimbingan dan Konseling atau konselor adalah guru pemegang sertifikat pendidikan(Ganita Komalasari, 2014). 
Konseling adalah suatu kegiatan yang amat penting dalam kegiatan bimbingan konseling di sekolah maupun di luar sekolah, konseling merupakan aktifitas penting dalam merubah pemikiran, sikap, dan perilaku individu, yang dalam prosesnya harus dilaksanakan oleh seorang konselor yang profesional. Sebagai sebuah proses yang profesional, maka untuk melaksanakan konseling diperlukan seperangkat teori dan pendekatan yang mendasarinya, dan para konselornyapun adalah orang-orang yang khusus mendapatkan pendidikan untuk itu(Erhamwilda, 2009).

Pada saat pra-lahirnya BK pola 17 di Indonesia muncul berbagai kritikan dan persepsi negatif terhadap pelaksanaan Bimbingan dan Konseling diantaranya,Konselor sekolah dianggap polisi sekolah. BK dianggap semata-semata sebagai pemberi nasihat. Profesi BK dibatasi pada menangani masalah yang insidental, dan untuk klien-klien tertentu saja. BK melayani "orang sakit" dan atau "kurang normal". BK bekerja sendiri, konselor sekolah harus aktif, sementara pihak lain pasif. Adanya anggapan bahwa pekerjaan BK dapat dilakukan oleh siapa saja. Pelayanan BK berpusat pada keluhan pertama saja. Hasil pekerjaan BK harus dilihat. Cara pemecahan masalah bagi semua klien disamaratakan. Usaha BK dipusatkan pada penggunaan instrumentasi BK (tes, inventori, angket, dll). BK dibatasi untuk menangani masalah-masalah yang ringan saja. Kondisi-kondisi yang seperti ini, nyaris terjadi pada setiap sekolah di Indonesia pada saat itu(Salahudin, 2010).

Seiring berkembangnya zaman, kedudukan bimbingan dan konseling di sekolah menjadi sangat vital dengan lahirnya BK pola 17 yang mencakup; wawasan dasar bimbingan dan konseling yang meliputi pengertian, tujuan, fungsi, prinsip, dan asas-asas BK. Empat bidang bimbingan, yaitu bimbingan pribadi, bimbingan sosial, bimbingan belajar, dan bimbingan karir. Tujuh jenis layanan, yaitu layanan orientasi, informasi, penempatan/penyaluran, pembelajaran, konseling perorangan, bimbingan kelompok, dan konseling kelompok. Lima jenis kegiatan pendukung, yaitu instrumentasi bimbingan dan konseling, himpunan data, konferensi kasus, kunjungan rumah, dan alih tangan kasus(Salahudin, 2010).

Setelah lahirnya BK pola 17 pelayanan Bimbingan dan Konseling menemukan titik terang, diiringi munculnya SK Menpan No.84/1993 Pasal 4 ditegaskan bahwa tugas pokok guru pembimbing adalah "menyusun program BK, melaksanakan Program BK, evaluasi pelaksanaan program BK, analisis hasil pelaksanaan program BK, dan menindaklanjuti program BK terhadap peserta didik yang menjadi tanggung jawabnya". Unsur-unsur utama yang terdapat di dalam tugas pokok guru pembimbing meliputi: bidangbidang bimbingan; jenis-jenis layanan bimbingan dan konseling; jenis-jenis kegiatan pendukung bimbingan dan konseling; tahapan pelaksanaan program bimbingan dan konseling; jumlah siswa yang menjadi tanggung jawab guru pembimbing untuk memperoleh bimbingan dan konseling (minimal 150 orang). Dengan demikian, setiap kegiatan bimbingan dan konseling merupakan bentuk "tiga dimensi" dari sub-sub unsur "bidang layanan, jenis-jenis, dan pendukung tahapan tersebut"(Departemen Pendidikan Nasional Direktorat Jenderal Pendidikan Dasar dan Menengah, 2003).

Dengan adanya BK pola 17 ini, diharapkan siswa mendapatkan pelayanan BK secara maksimal dan memuaskan di sekolah. Persepsi siswa terhadap guru BK akan baik jika guru BK memberikan pelayanan yang baik dan sesuai dengan kebutuhan siswa, sebaliknya persepsi siswa terhadap guru BK akan kurang baik apabila guru BK memberikan pelayanan BK yang kurang sesuai dengan kebutuhan siswa, pelayanannya tidak terarah, apalagi jika kembali ke pola lama yakni guru BK bertindak sebagai polisi sekolah yang memburu dan menghukum siswa bukan menyadarkan dan memberi pencerahan kepada siswa.

Pelaksanaan layanan bimbingan dan konseling (BK pola 17) oleh guru BK di SMA Negeri 5 Mataram sudah dijalankan dengan baik. Guru BK di sekolah tersebut adalah guru BK profesional yang berjumlah 3 orang dengan berbagai latar belakang pendidikan. Guru BK di sekolah ini selalu siap kapanpun siswa membutuhkan layanan bimbingan dan konseling, apalagi layanan informasi yang selalu disiapkan dan diberikan karena kebutuhan siswa akan informasi seperti pendidikan dan karir, akan tetapi persepsi siswa terhadap guru BK akan berbeda antara satu dengan yang lainnya tergantung bagaimana siswa menilai guru BK.

\section{Method}

Jenis penelitian ini adalah penelitian kuantitatif dengan metode deskriptif. Penelitian deskriptif (descriptive research) adalah metode penelitian yang ditunjukkan untuk mendeskripsikan atau menggambarkan fenomena-fenomena yang ada, baik fenomena yang bersifat alamiah ataupun rekayasa manusia, yang berlangsung pada saat ini atau pada saat yang lampau. Penelitian ini mengkaji bentuk aktivitas, karakteristik, perubahan, hubungan, kesamaan dan perbedaannya dengan fenomena lain. Penelitian ini tidak mengadakan manipulasi atau memberikan perlakuan-perlakuan tertentu terhadap variabel atau pengubahan pada variabel-variabel bebas, tetapi semua kegiatan, keadaan, kejadian, aspek komponen berjalan sebagaimana kondisi apa adanya. Penggambaran kondisi bisa dalam bentuk individual ataupun kelompok, dan menggunakan angka-angka(Nana Syaodih Sukmadinata, 2013). 
Menurut Sugiyono, "variabel merupakan gejala yang menjadi fokus peneliti untuk diamati". Variabel dalam penelitian ini yaitu persepsi siswa terhadap pelaksanaan layanan bimbingan dan konseling di sekolah oleh guru BK. Variabel tersebut adalah variabel tunggal, sehingga tidak ada hubungan antar variabel, baik variabel yang mempengaruhi (independen) dan variabel yang dipengaruhi (dependen)(Sugiyono, 2014).

Persepsi siswa tentang pelaksanaan layanan bimbingan dan konseling oleh guru BK di sekolah yaitu pemahaman atau pandangan siswa mengenai pelaksanaan layanan bimbingan dan konseling oleh guru BK untuk siswa itu sendiri. Indikatornya adalah pelaksanaan layanan BK di sekolah yang meliputi: kedisiplinan dan penampilan guru BK, wawasan BK, bidang bimbingan, jenis layanan BK, kegiatan pendukung BK, kinerja dan keterampilan guru BK melaksanakan pelayanan BK di sekolah.

Menurut Margono, populasi adalah seluruh data yang menjadi perhatian kita dalam suatu ruang lingkup dan waktu yang kita tentukan(Margono, 2010). Sedangkan Sugiyono mengatakan, populasi adalah daerah generalisasi yang terdiri atas subjek dan objek yang mempunyai kualitas dan karakteristik tertentu yang ditetapkan oleh peneliti untuk dipelajari dan kemudian ditarik kesimpulannya(Sugiyono, 2016).

Berdasarkan kedua pendapat di atas, maka yang dimaksud dengan populasi adalah keseluruhan individu baik subyek maupun obyek yang dilibatkan dalam penelititan, maka yang menjadi populasi subyek dalam penelitian ini adalah seluruh siswa di SMA Negeri 5 Mataram dari kelas X, XI, dan XII yang berjumlah 1104 orang. Sedangkan populasi obyek dalam penelitian ini adalah persepsi siswa terhadap pelaksanaan layanan Bimbingan dan Konseling oleh guru BK di sekolah. Berikut ini akan disajikan tabel mengenai populasi penelitian.

Menurut Sugiyono, teknik sampling merupakan teknik pengambilan sampel(Sugiyono, 2016). Dalam penelitian ini teknik yang digunakan adalah Stratified Proportional Random Sampling. Menurut Sugiyono Stratified Proportional Random Sampling merupakan teknik yang digunakan apabila populasi mempunyai anggota atau unsur yang tidak homogen dan berstrata secara proporsional(Sugiyono, 2016). Hubungannya dengan penelitian ini teknik Stratified Proportional Random Sampling dipergunakan karena siswa-siswa yang akan diteliti terdiri dari beberapa kelas dan akan diambil secara proporsi di masing-masing kelas, di mana setiap individu dari masing-masing kelas memiliki kesempatan yang sama untuk menjadi anggota sampel.

Dalam menentukan sampel penelitian ilmiah memiliki peran penting, karena jika teknik pengambilan sampelnya salah maka data yang diperoleh salah. Sedangkan penentuan jumlah sampel tergantung pada besarnya jumlah populasi. jika populasi kurang dari 100, dianjurkan agar semua dijadikan sampel, namun jika populasi lebih dari 100, maka dapat diambil 10-15\%, 20-25\% atau lebih tergantung kemampuan peneliti(Arikunto, 2011).

Berdasarkan pendapat di atas. Maka besarnya jumlah sampel yang akan diambil dalam penelitian ini adalah 20\%. Populasinya 1104 x 20\% = 220,1 yang dibulatkan menjadi 234 siswa karena pengambilan sampel dari masing-masing angkatan dari kelas X, XI, dan XII agar mewakili seluruh populasi. Maka sampel yang akan diambil dalam penelitian ini adalah 234 siswa. Berikut ini akan disajikan tabel mengenai sampel penelitian.

Instrumen dalam penelitian ini berupa angket sebagai instrumen inti/pokok dan satu-satunya yang digunakan dalam penelitian ini. Adapun kisi-kisi instrument (angket) yang berkaitan dengan data yang akan didapatkan dalam penelitian ini, maka angket yang akan dibuat sebanyak 58 item kesemuanya itu dalam bentuk angket tertutup. Tujuannya untuk mengetahui data tentang persepsi siswa terhadap pelaksanaan layanan BK oleh guru BK disekolah. Untuk teknik pemberian skor terhadap setiap pilihan dengan penjelasan sebagai berikut: untuk jawaban pertanyaan "Sangat Baik" diberi skor 4 (empat), jawaban pertanyaan "Baik" diberi skor 3 (tiga), jawaban yang dianggap "Tidak Baik" diberi skor 2 (dua), dan jawaban yang dianggap "Sangat Tidak Baik" diberi skor 1 (satu)(Sugiyono, 2016).

Kegiatan analisis data merupakan mengelompokkan data berdasarkan variabel, jenis responden, dan tabulasi data berdasarkan variabel dari seluruh responden, menyajikan data tiap variabel yang diteliti, melakukan perhitungan untuk menjawab rumusan masalah, dan melakukan perhitungan untuk menguji hipotesis yang telah diajukan(Sugiyono, 2014). Teknik analisis data yang digunakan dalam penelitian ini adalah menggunakan teknik deskriptif distribusi frekuensi dan persentase dengan bantuan program software SPSS versi 17 for windows.

\section{Results and Discussions}

Persepsi atau tanggapan adalah proses mental yang terjadi pada diri manusia yang akan menunjukan bagaimana kita melihat, mendengar, merasakan, serta meraba (kerja indra) di sekitar kita. Wiliam James mengatakan, persepsi adalah suatu pengalaman yang berbentuk berupa data-data yang didapat melalui indra, hasil pengolahan otak dan ingatan selanjunya dihayati melalui ilusi. Ilusi itu sebenarnya pengalaman aktual berupa data masukan yang tidak diterjemahkan sebagaimana adanya dan ada tambahan berupa pengolahan otak dari hasil-hasil pengalaman yang lalu(Tri Rusmi Widayatun, 2009). 
Persepsi merupakan tahap paling awal dari serangkaian pemroses informasi. Persepsi adalah proses penggunaan pengetahuan yang telah dimiliki (yang disimpan dalam ingatan) untuk mendeteksi atau memperoleh dan menginterpretasi stimulus (rangsangan) yang diterima oleh alat indra. Secara singkat dapat dikatakan bahwa persepsi adalah suatu proses menginterpretasi atau menafsirkan informasi yang diperoleh melalui sistem alat indra manusia. Misalnya, pada waktu seorang melihat sebuah gambar, membaca tulisan, atau mendengarkan suara tertentu, ia akan melakukan interpretasi berdasarkan pengetahuan yang dimilikinya dan yang relevan dengan hal-hal itu(Suhernan, 2005).

Berdasarkan pemahaman tersebut, maka persepsi mencakup dua proses yang berlangsung secara serempak antara keterlibatan aspek-aspek dunia luar (stimulus-informasi) dengan dunia di dalam diri seseorang (pengetahuan yang relevan dan telah disimpan dalam ingatan). Dua proses di dalam persepsi itu disebut bottom-up atau data driven processing (aspek stimulus), dan top-down atau conceptually driven processing (aspek pengetahuan seseorang). Hasil persepsi seseorang mengenai sesuatu obyek di samping dipengaruhi oleh penampilan obyek itu sendiri, juga pengetahuan seseorang mengenai obyek itu. Dengan demikian, suatu obyek dapat dipersepsi berbeda oleh dua orang, akibat perbedaan pengetahuan yang dimiliki masing-masing orang mengenai obyek itu, misalnya, orang yang baru pertama kali mengikuti tes psikologi akan menganggap tes psikologi itu sulit, namun bagi mereka yang sudah beberapa kali mengikuti tes tersebut akan menganggap tes tersebut tidak sulit. Ada tiga aspek di dalam persepsi yang dianggap sangat relevan dengan kognisi manusia, yaitu: Pertama Pencatatan Indra (Sensory Register). Kedua Pengenalan pola. Ketiga Perhatian (Attention)(Suhernan, 2005).

Pertama terjadinya persepsi adalah karena adanya obyek/stimulus yang merangsang untuk ditangkap oleh panca indra (obyek tersebut menjadi perhatian panca indra), kemudian stimulus/obyek perhatian tadi dibawa ke otak, dari otak terjadi adanya "kesan" atau jawaban (response) adanya stimulus, berupa kesan atau respons dibalikkan ke indra kembali berupa "tanggapan" atau persepsi atau hasil kerja indra berupa pengalaman hasil pengolahan otak. Proses terjadinya persepsi ini perlu fenomena, dan yang terpenting fenomena dari persepsi ini adalah "perhatian "atau" attention ". Pengertian perhatian itu sediri adalah suatu konsep yang diberikan pada proses persepsi yang menseleksi input-input tertentu untuk diikutsertakan dalam suatu pengalaman yang kita sadari/kenal dalam suatu waktu tertentu(Tri Rusmi Widayatun, 2009).

Menurut Walgito, ada beberapa jenis persepsi yaitu: persepsi melalui indra pendengaran, persepsi melalui indra penciuman, persepsi melalui indra pengecap dan persepsi melalui indra kulit atau perasa. Sedangkan menurut Irwanto, ada dua jenis persepsi yaitu, Persepsi positif, yaitu persepsi yang menggambarkan segala pengetahuan dan tanggapan yang selaras dengan obyek persepsi yang diteruskan dengan upaya pemanfaatannya. Persepsi negatif, yaitu persepsi yang menggambarkan segala pengetahuan dan tanggapan yang tidak selaras dengan obyek persepsi. Hal ini akan diteruskan dengan kepastian untuk menerima atau menolak dan menentang segala usaha obyek yang dipersepsikan(Athiyyatun Najah, 2007).

Kata konseling (Counseling) berasal dari kata counsel yang diambil dari bahasa Latin yaitu counsilium, artinya "bersama" atau "bicara bersama". Pengertian "berbicara bersama-sama" dalam hal ini adalah pembicaraan konselor (counselor) dengan seorang atau beberapa klien (counselee). Kesimpulannya konseling merupakan salah satu upaya untuk membantu mengatasi konflik, hambatan, dan kesulitan dalam memenuhi kebutuhan, sekaligus upaya peningkatan kesehatan mental(Latipun, 2001).

Pada bagian lain Prayitno, mendefinisikan bimbingan sebagai bantuan yang diberikan kepada individu untuk dapat memilih, mempersiapkan diri, dan memangku suatu jabatan serta mendapat kemajuan dalam jabatan yang dipilihnya. Sedangkan konseling diartikan sebagai kegiatan pengungkapan fakta atau data tentang siswa, serta pengarahan kepada siswa untuk dapat mengatasi sendiri masalah-masalah yang dihadapinya. Dalam konteks ini, sejalan dengan peraturan pemerintah No.28/1990 tentang pendidikan dasar pasal 25 ayat 1, dikatakan bahwa "Bimbingan merupakan bantuan yang diberikan kepada siswa dalam rangka upaya menemukan pribadi, mengenal lingkungan, dan merencanakan masa depan"(Departemen Pendidikan Nasional Direktorat Jenderal Pendidikan Dasar dan Menengah, 2003).

Sedangkan dalam konteks pengertian konseling islami, H.M. Arifin mendefinisikan, konseling islami merupakan segala kegiatan yang dilakukan oleh seseorang, dalam rangka memberikan bantuan kepada orang lain melalui petunjuk yang diajarkan oleh Al-Qur'an dan Al-Hadis, yang mengalami kegelisahan-kegelisahan rohaniah dalam lingkungan hidupnya agar orang tersebut mampu mengatasi masalahnya sendiri, karena timbul kesadaran atas penyerahan diri terhadap kekuasaan Allah SWT. Hingga timbul pada diri pribadinya suatu cahaya harapan kebahagiaan hidup saat sekarang dan masa depannya(Erhamwilda, 2009).

Tujuan umum pelayanan bimbingan dan konseling pada dasarnya sejalan dengan tujuan pendidikan itu sendiri, karena bimbingan dan konseling merupakan bagian integral dari sistem pendidikan. Menilik pada undang-undang Nomor 2 Tahun 1989 tentang Sistem Pendidikan Nasional, tujuan pendidikan adalah terwujudnya manusia Indonesia seutuhnya yang cerdas, yang beriman dan bertaqwa kepada Tuhan Yang Maha Esa dan berbudi pekerti yang luhur, memiliki pengetahuan dan keterampilan, kesehatan jasmani dan rohani, kepribadian yang mantap dan mandiri, serta rasa tanggung jawab kemasyarakatan dan kebangsaan. 
Secara khusus tujuan bimbingan dan konseling di sekolah adalah untuk membantu siswa agar dapat mencapai tujuan-tujuan perkembangan yang meliputi aspek pribadi, sosial, belajar dan karir(Erhamwilda, 2009).

Hasil penelitian secara keseluruhan merupakan hasil distribusi frekuensi dan persentase dari semua indikator yang meliputi indikator kedisiplinan dan penampilan guru BK, indikator wawasan BK, indikator bidang bimbingan, indikator jenis layanan $\mathrm{BK}$, indikator kegiatan pendukung $\mathrm{BK}$, indikator kinerja dan keterampilan guru BK melaksanakan pelayanan BK di sekolah. Berikut akan disajikan hasil penelitian secara keseluruhan:

Tabel Distribusi Frekuensi dan Persentase Hasil Penelitian Secara Keseluruhan
\begin{tabular}{|l|l|ll|l|l|}
\hline No & Kategori & Interval & F & P (\%) \\
\hline 1 & Sangat Tidak Baik & $1,00-1,75$ & 0 & $0,00 \%$ \\
\hline 2 & Tidak Baik & $1,76-2,51$ & 3 & $1,28 \%$ \\
\hline 3 & Baik & $2,52-3,27$ & 160 & $68,38 \%$ \\
\hline 4 & Sangat Baik & $3,28-4,00$ & 71 & $30,34 \%$ \\
\hline
\end{tabular}
Jumlah

Berdasarkan tabel di atas, dapat disimpulkan bahwa persepsi siswa terhadap pelaksanaan layanan BK di sekolah oleh guru BK di SMAN 5 Mataram, kategori sangat tidak baik sebanyak 0,00\% dengan frekuensi 0 , kategori tidak baik sebanyak 1,28\% dengan frekuensi 3, kategori baik sebanyak 68,38\% dengan frekuensi 160, dan kategori sangat baik sebanyak 30,34\% dengan frekuensi 71.

\section{Grafik Distribusi Frekuensi dan Persentase Hasil Penelitian Secara Keseluruhan}

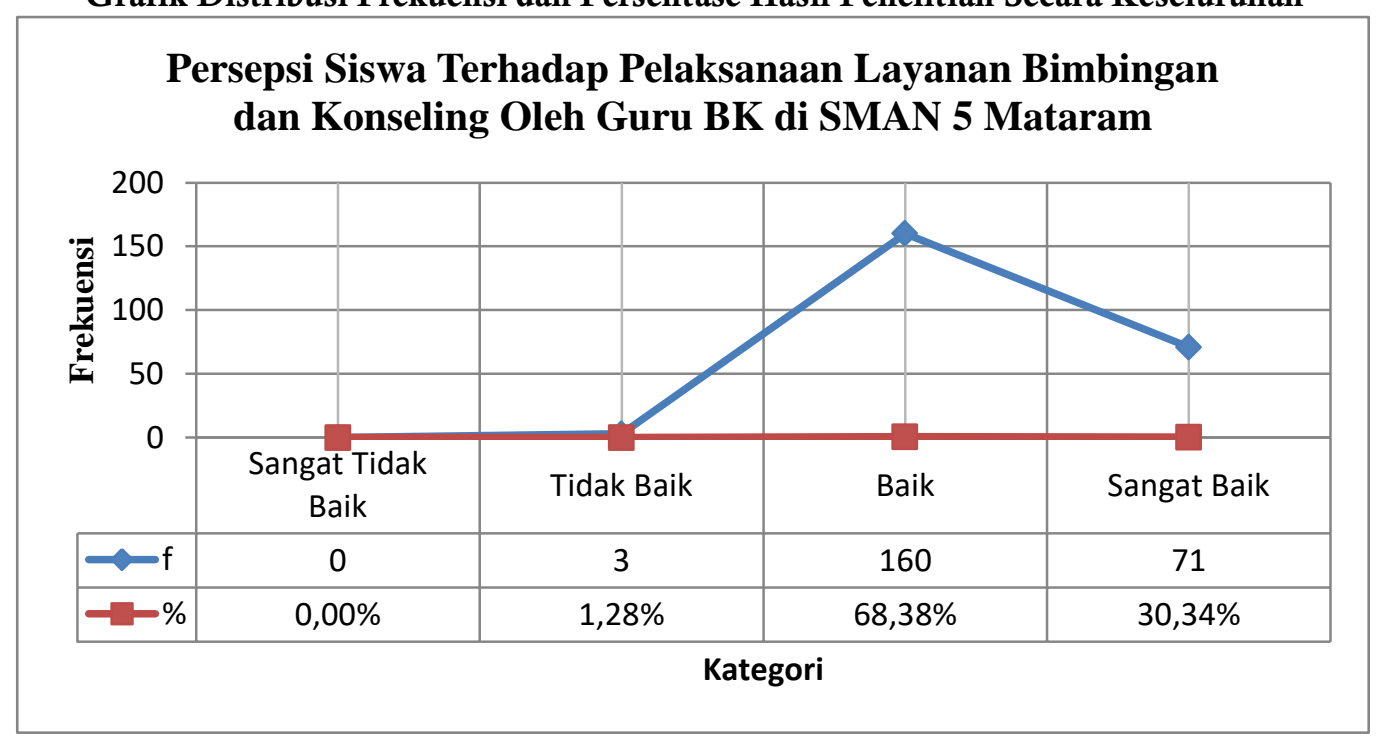

Indikator pertama adalah kedisiplinan dan penampilan guru BK yang meliputi pakaian guru BK, penampilan atau cara guru BK membawa diri, ketepatan waktu saat guru BK hadir di sekolah, dan kehadiran guru BK di sekolah. hasilnya bahwa persepsi siswa terhadap pelaksanaan layanan BK di sekolah pada indikator kedisiplinan dan penampilan guru BK, kategori sangat tidak baik sebanyak 0,43\% dengan frekuensi 1, kategori tidak baik sebanyak 3,42\% dengan frekuensi 8 , kategori baik sebanyak $61,97 \%$ dengan frekuensi 145, dan kategori sangat baik sebanyak 34,19\% dengan frekuensi 80 . Kesimpulannya adalah nilai tertinggi menunjukkan bahwa indikator kedisiplinan dan penampilan guru BK dalam kategori baik menurut persepsi siswa SMAN 5 Mataram. Item yang paling dominan dan paling tinggi nilainya adalah item persepsi siswa terhadap cara guru BK dalam berpakaian di sekolah.

Indikator kedua adalah wawasan bimbingan dan konseling yang meliputi pengertian BK, tujuan BK, Fungsi BK, prinsip BK, dan asas-asas BK. hasilnya bahwa persepsi siswa terhadap pelaksanaan layanan BK di sekolah pada indikator wawasan bimbingan dan konseling, kategori sangat tidak baik sebanyak $0,00 \%$ dengan frekuensi 0 , kategori tidak baik sebanyak 0,43\% dengan frekuensi 1, kategori baik sebanyak $58,55 \%$ dengan 
frekuensi 137, dan kategori sangat baik sebanyak 41,03\% dengan frekuensi 96. Kesimpulannya adalah nilai tertinggi menunjukkan bahwa indikator wawasan bimbingan dan konseling dalam kategori baik menurut persepsi siswa SMAN 5 Mataram. Item yang paling dominan dan paling tinggi nilainya adalah item persepsi siswa terhadap kemampuan guru BK dalam memberikan motivasi ke siswa.

Indikator ketiga adalah bidang bimbingan yang meliputi bimbingan pribadi, bimbingan belajar, bimbingan sosial, dan bimbingan karir. Hasilnya bahwa persepsi siswa terhadap pelaksanaan layanan BK di sekolah pada indikator bidang bimbingan, kategori sangat tidak baik sebanyak $0,00 \%$ dengan frekuensi 0 , kategori tidak baik sebanyak 1,28\% dengan frekuensi 3, kategori baik sebanyak 67,09\% dengan frekuensi 157 , dan kategori sangat baik sebanyak 31,62\% dengan frekuensi 74 . Kesimpulannya adalah nilai tertinggi menunjukkan bahwa indikator bidang bimbingan dalam kategori baik menurut persepsi siswa SMAN 5 Mataram. Item yang paling dominan dan paling tinggi nilainya adalah item persepsi siswa terhadap kemampuan guru BK dalam menanamkan sikap dan kebiasaan dalam beriman dan bertaqwa kepada Tuhan Yang Maha Esa.

Indikator keempat adalah jenis layanan bimbingan dan konseling yang meliputi layanan orientasi, layanan informasi, layanan penempatan atau penyaluran, layanan konseling individu, layanan bimbingan kelompok, dan layanan konseling kelompok. Hasilnya bahwa persepsi siswa terhadap pelaksanaan layanan BK di sekolah pada indikator jenis layanan bimbingan dan konseling, kategori sangat tidak baik sebanyak $0,00 \%$ dengan frekuensi 0 , kategori tidak baik sebanyak 2,99\% dengan frekuensi 7 , kategori baik sebanyak $66,24 \%$ dengan frekuensi 155 , dan kategori sangat baik sebanyak 30,77\% dengan frekuensi 72 . Kesimpulannya adalah nilai tertinggi menunjukkan bahwa indikator jenis layanan bimbingan dan konseling dalam kategori baik menurut persepsi siswa SMAN 5 Mataram. Item yang paling dominan dan paling tinggi nilainya adalah item persepsi siswa terhadap kemampuan guru BK dalam memberikan jalan keluar bagi masalah siswa dalam proses konseling individu.

Indikator kelima adalah kegiatan pendukung bimbingan dan konseling yang meliputi instrumentasi bimbingan dan konseling, himpunan data, konferensi kasus, kunjungan rumah, dan alih tangan kasus. Hasilnya bahwa persepsi siswa terhadap pelaksanaan layanan BK di sekolah pada indikator kegiatan pendukung bimbingan dan konseling, kategori sangat tidak baik sebanyak 0,43\% dengan frekuensi 1 , kategori tidak baik sebanyak 4,70\% dengan frekuensi 11, kategori baik sebanyak 76,50\% dengan frekuensi 179 , dan kategori sangat baik sebanyak $18,38 \%$ dengan frekuensi 43 . Kesimpulannya adalah nilai tertinggi menunjukkan bahwa indikator kegiatan pendukung bimbingan dan konseling dalam kategori baik menurut persepsi siswa SMAN 5 Mataram. Item yang paling dominan dan paling tinggi nilainya adalah item persepsi siswa terhadap kemampuan guru BK dalam menggunakan komputer/laptop untuk kepentingan program layanan bimbingan dan konseling.

Indikator keenam adalah kinerja dan keterampilan guru BK melaksanakan pelayanan BK di sekolah yang meliputi tahap perencanaan, tahap pelaksanaan, tahap evaluasi, tahap analisis, dan tahap tindak lanjut. Hasilnya bahwa persepsi siswa terhadap pelaksanaan layanan BK di sekolah pada indikator kinerja dan keterampilan guru BK melaksanakan pelayanan BK di sekolah, kategori sangat tidak baik sebanyak $0,00 \%$ dengan frekuensi 0, kategori tidak baik sebanyak 1,28\% dengan frekuensi 3, kategori baik sebanyak 70,94\% dengan frekuensi 166, dan kategori sangat baik sebanyak 27,78\% dengan frekuensi 65. Kesimpulannya adalah nilai tertinggi menunjukkan bahwa indikator kinerja dan keterampilan guru BK melaksanakan pelayanan BK di sekolah dalam kategori baik menurut persepsi siswa SMAN 5 Mataram. Item yang paling dominan dan paling tinggi nilainya adalah item persepsi siswa terhadap kemampuan guru BK dalam mengidentifikasi/mengenali kasus siswa sebelum memberikan penanganan.

Berdasarkan enam indikator di atas, hasil keseluruhannya menunjukkan bahwa persepsi siswa dalam kategori baik. Hal ini mengindikasikan bahwa teori proses terjadinya persepsi yang mengatakan bahwa persepsi terjadi karena adanya stimulus yang disimpan dalam otak sehingga menghasilkan respon. Jadi persepsi siswa terhadap pelaksanaan layanan bimbingan dan konseling oleh guru BK di SMA Negeri 5 Mataram dipengaruhi oleh stimulus yang diberikan oleh guru BK saat pemberian layanan BK di sekolah. Stimulus yang dimaksud adalah kedisiplinan dan penampilan guru BK, wawasan BK bidang bimbingan, jenis layanan BK, kegiatan pendukung BK, kinerja dan keterampilan guru BK melaksanakan pelayanan BK di sekolah.

\section{Conclusions}

Berdasarkan hasil penelitian yang telah dilakukan, distribusi frekuensi dan persentase dari semua indikator yang meliputi indikator kedisiplinan dan penampilan guru BK, indikator wawasan BK, indikator bidang bimbingan, indikator jenis layanan BK, indikator kegiatan pendukung BK, indikator kinerja serta keterampilan guru BK melaksanakan pelayanan BK di sekolah, maka dapat disimpulkan bahwa persepsi siswa terhadap pelaksanaan layanan BK di sekolah oleh guru BK di SMAN 5 Mataram menunjukkan dalam katagori baik yakni dengan sumbangan frekuensi 160 atau 68,38 \% dari kriteria yang sudah ditentukan 


\section{Acknowledgments}

Penulis mengucapkan terimakasih terhadap sekolah SMAN 5 Mataram yang sudah memberikan kami izin untuk melalukan penelitian. Terima kasih kepada seluruh informan dalam penelitian ini, kepala sekolah, guru bimbingan konseling, guru dan para siwa-siswi SMAN 5 Mataram. Serta kepada peer reviewer mahasiswa Bimbingan dan Konseling Islam. Semoga karya tulis ini dapat bermanfaat untuk semua dan khususnya di bidang Bimbingan dan Konseling

\section{References}

Arikunto, S. (2011). Prosedur Penelitian (Ed. Rev. V). Rineka Cipta.

Athiyyatun Najah. (2007). , "Hubungan Antara Persepsi Anak Terhadap Pola Asuh Orang Tua Dengan Prestasi Belajar." , Fakultas Psikologi Universitas Muhammadiyah Surakarta, 18.

Departemen Pendidikan Nasional Direktorat Jenderal Pendidikan Dasar dan Menengah. (2003). Dasar-Dasar Bimbingan dan Konseling. Balai Penataran Guru Mataram.

Erhamwilda. (2009). Konseling Islami. Graha Ilmu.

Ganita Komalasari, E. W. dan karsih. (2014). Teori dan Teknik Konseling. Indeks.

Latipun. (2001). Psikologi Konseling. UMM Press.

Margono. (2010). Metodelogi Penelitian Pendidikan. Bumi Aksara.

Nana Syaodih Sukmadinata. (2013). Metode Penelitian Pendidikan. Remaja Rosakarya.

Salahudin, A. (2010). Bimbingan dan Konseling. Pustaka Setia.

Sugiyono. (2014). Statistika Untuk Penelitian. Alfabeta.

Sugiyono. (2016). Metodelogi Penelitian Kuantitatif, KualitatifDan R\&D. Alfabeta.

Suhernan. (2005). Psikologi Kognitif. Srikandi.

Tri Rusmi Widayatun. (2009). Ilmu Perilaku. Sagung Seto. 